\title{
13 The Role of External Financing in the Development of Social Entrepreneurship in CEE Countries
}

\author{
Danijel Baturina, Melinda Mihály, \\ Erila Haska, Anna Ciepielewska-Kowalik, \\ Juliana Kiss, Ariola Agolli, Marija \\ Bashevska, Jana Korunovska Srbijanko, \\ Dina Rakin and Vladimir Radojičić
}

\section{Introduction}

The forms and methods of financing are, in general, crucial for the development of social-enterprise (SE) initiatives. Social entrepreneurship is characterised by hybridity, which means that it relies on a resource mix including different types of financing (Di Domenico et al. 2010; Austin et al. 2006): beyond market-based income, public funding stemming from international, national and/or local levels and different types of investments and donations are also important.

In Central and Eastern Europe (CEE), ${ }^{1}$ at the beginning of the political and economic transition period, there were no public-support policies (Galera 2016) or funding schemes designed for social enterprise (ICF 2014). Therefore, one of the key nudges for the emerging initiatives came from external financial sources, ${ }^{2}$ such as international development organisations and the EU. Third-sector organisations in CEE also made use of funding available from various international donors to participate in development projects (Kral 2013).

In this chapter, we are interested in the ways in which "external" financing influenced the development of the social-entrepreneurship field in CEE. In order to gain a better understanding of this issue, we compared supra-national financial sources available for SE development in six selected CEE countries—namely Albania, Croatia, Hungary, North Macedonia, Poland and Serbia. The countries we selected were at different levels of EU integration, which also enabled us to better understand the role of the EU in shaping the SE field in CEE.

Beyond the role of the EU, we identified two other external funding sources, namely SE development agencies and other international development agencies (such as the World Bank, UNDP and USAID). Through 
comparing these different external financing sources in the six countries under consideration, we aimed to spot tendencies or overarching mechanisms in the development of the SE field in and beyond CEE.

\section{Methodological Approach}

After the collapse of state socialism, international development ${ }^{3}$ aid started to arrive in CEE. Donor policies in "early-transition" countries played a particularly significant role because the national contexts were marked by a lack of government capacity (OECD 2006). A large part of private funding came from private foundations based mainly in Western Europe, the US or other rich countries (Spurga 2007). The European Union (EU) and other donors, such as the United Nations (UN) and the United States Agency for International Development (USAID) (European Movement 2015) were also recognised as a factor that shaped the development of CEE after the collapse of state socialism.

International aid supported the re-emergence of civil society, which had been oppressed during state socialism. At the beginning of the political and economic transition period, international aid mainly funded organisations dealing with democratisation, human rights and community building. Today, it can be argued that donors' perspective subsequently shifted from democratisation to introducing support mechanisms oriented towards active social policies and sustainable development, in which social enterprises fit well. The emergence of social entrepreneurship can mainly be linked to international funding sources.

The SE field in CEE is considered to be "less developed" than its Western European counterpart (Galera 2016; ICF 2014; Borzaga et al. 2008). Questioning the linear historical approach and in an attempt to avoid "self-colonisation", we-CEE researchers-aimed to understand the emergence of the SE field in CEE through shedding light on the major funding bodies and their agenda in SE development (their SE narratives). Therefore, our guiding research question was the following: "In which ways has external financial support (in the form of grants, subsidies, direct donations, seed funding) influenced the development of social entrepreneurship in CEE?”

Beside other international development agencies, the EU is highly influential in the region; we purposefully selected CEE countries that were at different levels in terms of EU integration. Poland and Hungary had become EU members already in 2004; Croatia joined the EU in 2013; and Albania, North Macedonia and Serbia are currently candidates for EU membership.

The methodological approach used in this study relied on desk research and country summaries. Desk research included a collection of secondary data based on available documents, reports, studies, strategies and other relevant documents regarding social entrepreneurship in the researched 
countries. Country summaries ${ }^{4}$ were mostly fed by contributions to the ICSEM project, which focused inter alia on the historical trajectories of social enterprises, as well as by reports prepared for the European Commission Report on Social Enterprises and their Ecosystems, ${ }^{5}$ which also paid attention to social enterprises' financing mix.

\section{Comparative Analysis of Six CEE Countries}

Our comparative analysis focuses on two broad issues. First, we briefly introduce the contexts wherein social enterprises emerge, develop and operate. Secondly, we aim to better understand how international actors influenced the development of the SE field in the six countries studied. As financial sources represent power, we attempt to outline, in this section, how international actors define social enterprise in their project of developing the field in CEE.

\subsection{National Contexts for Social Enterprise}

Although most of the countries analysed had a rich cooperative history before World War II, state socialism had a negative impact on civil-society initiatives and cooperatives. The concept of social enterprise only gained recognition in this region after the collapse of state socialism, when international development agencies stepped in to initiate and influence the development of the SE field. The concept emerged around 1995 in Hungary and Poland; in Albania, Croatia and North Macedonia, social entrepreneurship only started receiving attention in the new millennium.

EU funds became available to develop the SE field earlier in those countries that accessed the EU sooner (Hungary and Poland) ${ }^{6}$ than in the other four countries studied. In Albania, SE activities emerged shyly before 2000 as part of the activities of civil-society organisations (CSOs), but the real development only started around the year 2010 (Partners Albania 2013). In Croatia, the discourse on social entrepreneurship emerged around 2005 and became more pronounced from about 2013-2014 onwards (Šimleša et al. 2016; Vidović 2012). The discourse on social enterprise emerged in Serbia in the early 2000s, and it was partly driven by the influence of foreign donors (European Commission 2018). The concept of social enterprise emerged in the third-sector discourse in North Macedonia around 2008-2009, and social entrepreneurship is still considered as a relatively new phenomenon there (Srbijanko et al. 2016; Ilijevski and Iloska 2018).

The fields of SE activities range across a wide spectrum: agricultural production, education, social services to people in need, vocational training (Partners Albania 2016), access to employment (Republički zavod za statistiku 2014), training and information and communication services (Ilijevski et al. 2016). 
Most of the social enterprises are legally registered as associations, foundations and cooperatives (especially social cooperatives in Croatia, Hungary, Poland and, to a lesser extent, Serbia). Some social enterprises also operate under the legal form of (non-profit) limited-liability company (Ltd). With a view to overcoming taxation challenges, there are also cases where social enterprises exist under more than one legal form (for Hungary, for example, see G. Fekete et al. 2017).

Although the reliability of statistics on social enterprise is limited in CEE countries, some estimates of the size of the sector in the countries under consideration have been provided; they range from some 30 social enterprises (in North Macedonia) ${ }^{7}$ to a few thousand initiatives (in Poland). ${ }^{8}$ The definition of a social enterprise may vary across countries or from one funding body to the other. This also influences statistics and makes comparing numbers on social enterprises challenging. In this chapter, we do not use a unique definition, ${ }^{9}$ but we consider national (and donors') perspectives on social enterprise as relevant.

There is no specific law on social enterprise in any of the analysed countries, except in Albania, where a rather restrictive law was approved in 2016. As for the fiscal framework in the studied CEE countries, it is either scarce or fragmented and not favourable to social enterprises. Social enterprises operate under different laws connected to their legal forms. Social entrepreneurship is not identified in bottom-up dynamics; SE initiatives are rather shaped, in most of these countries, by various strategies or government calls/tenders. Beyond SE development agencies, the definition of "social enterprise" and "social entrepreneurship" in CEE countries has been strongly influenced by the European Commission (in almost all countries), as a high ratio of statefunded SE activities have been financed from the European Structural and Investment Funds (ESIF) in EU member states and from the Instrument for Pre-accession Assistance (IPA) for EU candidate countries and potential EU candidate countries in the Western Balkans. ${ }^{10}$ Among the CEE countries studied, Croatia has a distinct "Strategy for the development of social entrepreneurship". Poland has a specific governmental structure and a "Programme for social-economy development" (Ministerstvo Pracy/Polityki Spolecznej 2014). In Hungary, support to social enterprises is provided under the Economic Development and Innovation Operational Programme (EDIOP) and the Rural Development Programme (RDP), co-financed by the EU (G. Fekete et al. 2017). In other CEE countries, "social entrepreneurship" is mentioned in various government strategies, or in documents related to employment, development of small and medium enterprises, alleviation of poverty, or cooperation between the government and civil society. In these documents, by contrast, the terms "social economy" and "social enterprise" are rarely mentioned. 


\section{Baturina, Mihály, Haska et al.}

\subsection{External Financing and Its Effects on Social Entrepreneurship}

In most of the countries studied, the first "footprints" of social enterprise can be found in state socialism, in the form of cooperatives (as for example in Albania, North Macedonia and Serbia), or even long before that, during World War II (as in Poland), in the form of voluntary engagement and cooperatives. However, under state socialism, cooperatives were not autonomous initiatives set up by a group of citizens; they were controlled by the state. ${ }^{11}$ Such origins contrast with those of recent social enterprises, which emerged during the last two decades as part of the activities of non-profit projects, and which were often funded by supra-national organisations (Partners Albania 2013; Vidović 2012). Table 13.1 summarises the key aspects of external financing related to the development of social entrepreneurship in a comparative perspective.

On the basis of our country summaries, we consider external financing as significant, but concrete numbers are often missing or are difficult to obtain in official documents and statistics. Nevertheless, it is possible to outline the major funding bodies that influenced SE development in the analysed CEE countries. In terms of external financing, the role of SE development agencies, the EU and other international development agencies can be highlighted.

\section{SE Development Agencies}

SE development agencies preceded EU institutions and proved to be highly influential in the development of the SE field in CEE. The introduction of the concepts of "social entrepreneur" or "social enterprise" can be linked to these agencies' activities.

NESsT, a US-based SE development agency, was present in Croatia between 2005 and 2017 (Kadunc et al. 2014; Vidović 2019) and has also been present in Hungary since 2001 (G. Fekete et al. 2017). Financial sustainability and innovation are emphasised in the definition put forward by NESsT, which describes social enterprises as organisations consciously organising and operating entrepreneurial activity in order to solve societal challenges in an innovative way (Tóth et al. 2011: 5). NESsT has always put a strong emphasis on earned-income strategies of non-profit organisations; this approach could thus be considered to represent the SE "earned-income school of thought" (Defourny and Nyssens 2014). NESsT provides both capacity-building services and investment for potential social enterprises.

Ashoka, another international SE development agency, has been shaping the SE field in Poland since 1994 and in Hungary since 1995. Ashoka focuses on social entrepreneurs, that is, individuals who implement solutions that are changing systems, putting forward solutions to the world's 
Table 13.1 Key characteristics of external financing for social enterprise in a comparative perspective

\begin{tabular}{|c|c|}
\hline Relevant aspects & Comparative perspective-key characteristics \\
\hline $\begin{array}{l}\text { Periods of SE } \\
\text { recognition }\end{array}$ & $\begin{array}{l}\text { - Specific historical experiences related to the } \\
\text { cooperative sector under Soviet-type socialist regimes } \\
\text { and to workers' self-management under Yugoslav } \\
\text { socialism as backgrounds influencing behaviours in } \\
\text { post-socialist countries } \\
\text { - Some recognition in the mid-1990s in Poland and } \\
\text { Hungary (connected to SE development agencies and } \\
\text { later to the EU) } \\
\text { - Recognition of social enterprise approximately in the } \\
\text { last decade for non-EU countries (and Croatia) }\end{array}$ \\
\hline $\begin{array}{l}\text { External } \\
\text { financing } \\
\text { for social } \\
\text { enterprises }\end{array}$ & $\begin{array}{l}\text { - No specific data about the share of external funding in } \\
\text { the overall funding available to social enterprises } \\
\text { - SE development is often only one goal in multiple-goal } \\
\text { tenders } \\
\text { - SE activities are eligible for financing in the tenders } \\
\text { oriented towards other entities, like CSOs }\end{array}$ \\
\hline Main donors & $\begin{array}{l}\text { - EU (funds and pre-accession programmes) } \\
\text { - SE development agencies, such as NESsT, Ashoka and } \\
\text { Yunus Social Business } \\
\text { - Other international actors: foreign embassies, } \\
\text { foundations and development organisations, such as } \\
\text { UN, USAID and World Bank }\end{array}$ \\
\hline $\begin{array}{l}\text { Main type of } \\
\text { activities } \\
\text { funded }^{12}\end{array}$ & $\begin{array}{l}\text { - Work integration (or employment of marginalised } \\
\text { people) } \\
\text { - Social services and social inclusion of marginalised } \\
\text { people } \\
\text { - Rural development (mostly related to cooperatives) }\end{array}$ \\
\hline $\begin{array}{l}\text { Perception by the } \\
\text { general public } \\
\text { and by the } \\
\text { government }\end{array}$ & $\begin{array}{l}\text { - Reservations due to the legacy of "images" related to } \\
\text { socialism } \\
\text { - New area that remains relatively unrecognised } \\
\text { - Social enterprise as a concept coming from foreign } \\
\text { development aid (especially in post-Yugoslavian } \\
\text { countries) } \\
\text { - In some countries, stigmatisation of those CSOs that } \\
\text { accept funding from international donors (other than } \\
\text { the EU) }\end{array}$ \\
\hline
\end{tabular}

Source: Adapted by the authors, based on the different country contributions

most urgent social problems (Ashoka 2015). Ashoka represents the "social-innovation school of thought" (Defourny and Nyssens 2014) and supports "social entrepreneurs" through financial and professional means. Ashoka and NESsT cooperate with other funding bodies, such as banks (Bank Pekao SA) or foundations, which are often connected to banks (UniCredit Foundation, Erste Foundation). 


\section{Baturina, Mihály, Haska et al.}

Yunus Social Business has been carrying out projects in the Balkans since mid-2012. It was formally established in Albania in 2013, and since 2015, it has expanded its activities towards other non-EU Western Balkan countries, under the name "Yunus Social Business Balkans". Yunus Social Business Balkans also represents the "earned-income school of thought" in the region (Defourny and Nyssens 2014), as "it aims to address social issues through supporting the creation of start-ups/businesses that have potential to create social impact for the society". ${ }^{13}$ The organisation runs entrepreneurship inspiration/awareness campaigns, implements incubation/acceleration and investment-readiness programmes, facilitates access to financing and supports the development of an enabling entrepreneurship ecosystem in the region. ${ }^{14}$

\section{EU Funds and Pre-Accession Programmes}

Since the 1990s, "social enterprise" and "social innovation" have become increasingly characteristic of EU policies (Fougère et al. 2017). Social enterprise indeed fits the EU's ideals of "inclusive growth", "full employment" and "competitive market economy". On a discursive level, social enterprise is considered as both a vehicle of economic growth and a solution to social challenges (Fougère et al. 2017). Our analysis has revealed that the main sources of external financing in CEE are closely related to the EU. ${ }^{15}$ Hungary (Szabó and Márkus 2015) and Poland greatly benefited from pre-accession funds, and EU funds available after the accession boosted the SE field. Right after the accession of ten new EU member states, ${ }^{16}$ in 2004, SE initiatives were rapidly integrated into the ongoing EQUAL Community Initiative (2002-2008). EQUAL had a €3-billion EU budget, and it recognised the potential of the social economy and social enterprises to promote employment and social inclusion as well as to reduce inequalities in the labour market. The social economy was one of EQUAL's nine themes, with a focus on the creation of social businesses and the promotion of the entrepreneurial spirit (Ferreira et al. 2019). In Poland and Hungary, many social enterprises emerged in this period. These social enterprises operated mainly in the field of professional reintegration of disadvantaged groups.

As a result of Hungary and Poland's accession to the EU, in 2004, the concept of social economy gained importance in these countries' public policies; the legal form of social cooperative was introduced in both countries in 2006 (European Commission 2019). Due to a strong political recognition, social cooperatives, which were often municipalitybased rather than civilian-based, had good access to EU funds. These initiatives were expected to fulfil work-integration functions, and they received wide support via regional grant opportunities in Operational Programmes from the European Social Fund (Ciepielewska-Kowalik et al. 2015; G. Fekete et al. 2017). 
Hungarian social cooperatives are concentrated in peripheral rural areas, which are particularly affected by long-term unemployment. These organisations often rely dominantly on project-based funding, and they are expected to tackle the complex challenges of long-term unemployment (G. Fekete et al. 2014) and social exclusion. Due to generous-but project-based-EU support schemes, the number of social cooperatives in Hungary increased rapidly, from one in 2007 to 2,490 in 2015 (Havas and Molnár 2017). However, despite this tremendous growth in numbers, social cooperatives' size and contribution to employment remain relatively insignificant. ${ }^{17}$ Moreover, the latest pieces of legislation further limit the autonomy of these initiatives in Hungary (European Commission 2019).

In Croatia, although the first impetus for the creation of a socialentrepreneurship sector came from SE development agencies (Kadunc et al. 2014; Ivanković-Knežević et al. 2013), the sector is now mainly shaped by EU funds. For example, all the funding related to the first strategy for social-entrepreneurship development in the country relies on financial sources stemming from the EU (Baturina 2018). The social inclusion of marginalised groups and the field of WISEs are also highlighted in different strategies as areas in which social enterprise could be specifically developed and financed on a project basis through EU funds (Baturina 2018).

In non-EU countries (Albania, ${ }^{18}$ Macedonia [Ilijevski and Iloska 2018] and Serbia), the Instrument for Pre-accession Assistance (IPA) is open for financing a wide range of socially entrepreneurial activities, mostly through tenders that are oriented towards civil society. ${ }^{19}$ In Albania, EU funding is seen as an instrument to support wider social and economic development (also in civil-society and social-entrepreneurship areas).

In summary, the EU is highly influential in the studied CEE countries. Social enterprises are seen in EU-funded projects as having the potential to ease social tensions through fulfilling work-integration functions. However, project-based funding is not sufficient for these organisations to stay alive. Indeed, even though EU programmes provide a considerable amount of funds for developing the SE field, civilian-based organisations (especially smaller social enterprises) encounter challenges in accessing these funds. Tenders are written in a way that benefits large organisations, which are politically less autonomous (see, for example, European Commission [2019] for an analysis of this issue in the Hungarian context, or Baturina [2016] for a similar analysis about Croatia).

\section{Other International Actors}

In the six CEE countries studied, we identified a variety of other international actors that had an impact in shaping the SE field. Foreign embassies, international foundations (such as the ERSTE Foundation and the 


\section{Baturina, Mihály, Haska et al.}

Open Society Foundation) and development organisations (such as UN programmes, USAID, Partners Albania, ${ }^{20}$ the World Bank, the British Council and the Swiss Agency for Development and Cooperation) are some of them.

The British Council shaped the conceptualisation of "social entrepreneurship" in Croatia and Serbia through its training programmes for social entrepreneurs titled "Skills for Social Entrepreneurs" (Kadunc et al. 2014). As the British Council defines social enterprise as "a business with primarily social objectives where surpluses are reinvested either in the business or in the community", ${ }^{21}$ its approach fits the "earned-income school of thought" (Defourny and Nyssens 2014). In Croatia, the Council also helped to form a pool of trainers that became part of the Social Entrepreneurship Forum (SEFOR) network (Kadunc et al. 2014).

Some international development organisations (such as USAID or the Swiss Agency for Development and Cooperation/Transition Assistance ${ }^{22}$ ) focused dominantly on the Western Balkans, which experienced high levels of unemployment and where many people remained on the margins of society due to the war in Yugoslavia. Both USAID and the Swiss Agency for Development played a role in financing enterprising civil-society organisations.

The EEA/Norway NGO Fund and Swiss-Hungarian NGO Grant and Scholarship Fund proved to be particularly important for civilian-based social enterprises in Hungary and Poland. As members of the European Economic Area (EEA) or the European Free Trade Association (EFTA), Iceland, Lichtenstein, Norway and Switzerland ${ }^{23}$ provided grants for the ten countries that joined the EU in 2004, with the aim of reducing social and economic disparities. But after 2014, politically autonomous civilian organisations (i.e. organisations that were independent from party politics) were openly attacked by the government in Hungary. The diplomacy conflict that has been escalating since 2014 between Norway and Hungary over the EEA/Norway NGO Fund and Swiss-Hungarian NGO Grant and Scholarship Fund (Kelemen-Varga et al. 2017) is very revealing of the attempt, on the part of the Hungarian government, to extend its control over funding sources dedicated to civilian organisations. Funding sources that are independent from the Hungarian government are increasingly being stigmatised. ${ }^{24}$ Similar processes, though on a lesser scale, can also be observed in Croatia, where the government is trying to put under tighter control funds for the civil society (Baturina 2016).

\section{Lessons From the Comparative Analysis}

There are a couple of lessons that can be drawn from this transversal analysis. First, although it can be argued that external financing was generally not crucial for the development of social enterprise throughout Western Europe (ICF 2014), it was clearly important for the development 
and the shaping of social entrepreneurship in CEE countries, ${ }^{25}$ which are situated on the semi-periphery of the global economy. The SE field did not receive enough public support, or had it developed sufficient selffinancing mechanisms or markets. ${ }^{26}$ External financing or donors are often seen in post-socialist countries as a "magic bullet", capable of solving all types of problems. In the countries we studied, however, we would rather conclude that it was more of a "trigger", in that it opened a path towards the recognition of social entrepreneurship as a new trend that can be beneficial to address some social challenges. Meanwhile, it is also important to emphasise that SE policy narratives may legitimise the welfare state's withdrawal from funding civil-society organisations that used to provide public services.

The second lesson is that different donors shape the SE field in different ways. SE development agencies, which preceded EU funds in Croatia, Hungary and Poland, have different approaches: while NESsT mainly focuses on strengthening the business approach of non-profit organisations, Ashoka is oriented towards strengthening the entrepreneurial and other skills of social entrepreneurs (through education or competitions). SE development agencies dominantly rely on US-based SE narratives ("earned income school of thought"), and they do not reflect on the socio-economic context for social enterprise in CEE. EU funding caused social entrepreneurship to develop more in areas, such as work integration (or employment of marginalised people), social services or rural development than in other areas, that were not targeted by EU funds. The EU's discourse on social enterprise fits into the EU's strategy, which focuses on inclusive growth, full employment and a competitive social market economy and in which territorial cohesion and social integration are priority areas. The other international actors (USAID, Open Society Foundation) sometimes focus on developing civilian-based social enterprises. As civilian-based initiatives are harder to control and may express criticisms about social policies, certain CEE governments may try, as we underlined earlier, to gain control over or cut their funding sources.

Among the different donors, the EU is the actor with the highest influence in shaping the SE field in the CEE countries that are at different levels of EU integration; this is our third lesson. Indeed, CEE countries have used EU funds to support the development of social entrepreneurship, both directly and indirectly. These sources significantly influenced the direction in which the SE sector has developed in the countries in our study that have joined the EU (Croatia, Hungary and Poland), but paradoxically, the EU's transformative potential is still higher in countries that have not joined it yet (Vandor et al. 2017). Analysis indeed shows that IPA greatly influences the development of social entrepreneurship in non-EU member states. Due to the availability of EU-based funding specifically intended for social enterprises, social enterprise appears in the strategic documents and social policy of the CEE member states of 


\section{Baturina, Mihály, Haska et al.}

the EU. In some cases, a new legal form (social cooperative in Croatia, Hungary, Poland and Serbia) is even created. On a discursive level, social enterprises with a work-integration function are expected to contribute to economic growth and the easing of social challenges (Fougère $e t$ al. 2017). As a result, social enterprises are faced with challenges in trying to meet the expectations of EU tenders. For example, social enterprises are expected to solve long-lasting social issues rooted in structural inequalities (such as long-term unemployment or social exclusion), but they only have access to project-based funding-which, by nature, is limited in time.

The fourth lesson is that, in all the studied countries, third-sector organisations consider the social entrepreneurial activity as having a self-financing potential. The increased reliance on market-based income could possibly be interpreted as a survival strategy of third-sector organisations in times of crisis (characterised by neoliberal policies of austerity and the shrinking role of the welfare state). ${ }^{27}$ Similar developments can be observed in the third sector in wider European contexts (Pape et al. 2016). In this respect, social entrepreneurship can be seen in CEE as part of a resilience strategy of the third sector, a widening of the scope of activities of third-sector organisations towards the market with a view to using all available resources to survive. Such a shift was supported by international actors providing knowledge and (external) financial resources to third-sector organisations.

\section{Conclusion}

Our analysis shows that external financing of social entrepreneurship, by introducing the SE concept in areas, such as employment, social inclusion and sustainable development, is seen as an investment in social development. However, such an approach towards social enterprise can also legitimise neoliberal policies and a further withdrawal of the national states from social service provision, and it can place too high expectations on the civil society, without providing it with appropriate funding to meet such expectations. Third-sector organisations in CEE clearly behave as rational actors when they adapt their activities to available financial sources.

Limitations of this study on the impact of external financing on social enterprise in CEE were related to the lack of available data. Therefore, we consider this analysis to be partly exploratory, and it should hopefully be followed by further research, looking into and deepening insight into external financing - which, as our analysis has shown, had and still has a significant impact on the development of social entrepreneurship in CEE. Our analysis confirmed that SE researchers need to reflect on how donors' priorities and narratives shape the SE field in CEE and beyond. 
Finally, reliance on external funding in CEE can be better apprehended when understanding that states in semi-peripheral countries tend to fund less welfare-related services delivered by third-sector organisations than what is the case in core countries (such as Western European ones). In addition, in CEE, the relationships between the state and civil society are characterised by democratic deficits and a lack of partnerships, and civilian-based social enterprises are hindered from fulfilling welfare functions due to their having only limited access to public funds. In short, there is still a long way to go to provide enabling ecosystems for social enterprises in CEE.

\section{Acknowledgements}

Anna Ciepielewska-Kowalik declares that the analysis regarding Poland in based on research financed by the National Science Centre Poland, within the framework of the project titled Co-production of welfare services: Education and social assistance policy in Poland after 1989 (No. 2015/19/D/HS5/00514).

\section{Notes}

1. The term "Central and Eastern Europe" is meant to include those countries that experienced state socialism in recent history.

2. Leś and Kolin (2009) observe that foreign aid, which provided technical assistance, know-how and financial backing to third-sector organisations, was one of the factors that contributed to the emergence of social enterprise in CEE.

3. For 50 years, "development" has provided a remarkably stable framework, within which the relationship between the "developer" (the affluent West) and the "developed" (the "others") has been understood (Mosse 2005). However, in current debates, "development" is subjected to critical scrutiny (Fischer-Tahir and Naumann 2013; Pike et al. 2006; Eversole 2014; Evans and Syrett 2007). While radicals question the relations of global inequality and cultural dominance implied in the idea of development itself, international development agencies devote their policy processes to constantly revising and re-framing development so as to shore up their legitimacy in a fast-changing political environment (Mosse 2005: 1).

4. The country summaries were written by Erila Haska and Ariola Agolli for Albania, Danijel Baturina for Croatia, Julianna Kiss and Melinda Mihaly for Hungary, Marija Bashevska and Jana Korunovska Srbijanko for North Macedonia, Anna Ciepielewska-Kowalik for Poland and Dina Rakin and Vladimir Radojičić for Serbia.

5. For more information, see European Commission (2020).

6. See Chapters 5 and 8 in the present volume.

7. The last "country fiche" about social enterprises and their ecosystem in Europe estimated, though, on the basis of a wider definition, that there were a few hundred social enterprises in North Macedonia (Ilijevski and Iloska 2018). 
8. The number of social enterprises is also obviously linked to the size of the country, but in any case, numbers must be considered as mere estimates, due to the fact that the definition of social enterprise varies from one country to the other and to the lack of official statistics.

9. Nor do we analyse different definitions in detail, as other studies do (see for example European Commission 2020).

10. In the countries studied, the use of the terms "social entrepreneurship" and "social enterprise" varies according to the country considered. In some countries, such as Poland, the notion of "social enterprise" has dominated the debate and it is the term that is most broadly recognised among the general public. In other countries, like Croatia, it is the notion of "social entrepreneurship" that dominates. Both concepts have been used in the public debate and at institutional level, though, so we analyse both while taking into account country-specific approaches.

11. See Chapter 12 for an analysis of this socialist legacy.

12. Estimated from available data, literature and country summaries.

13. Yunus Social Business Balkans: www.balkanimpact.com/about-us (accessed on May 29, 2019).

14. Yunus Social Business Balkans: www.balkanimpact.com/about-us (accessed on May 29, 2019).

15. Although such funds are not external per se for EU member states, they are often perceived in that way. Such perception is usually observed in particular during the accession period and the first years of membership, when the process of "Europeanisation" (Radaelli 2004) and "internalisation" of membership is not completed yet. A good example is provided by Croatia: after five years of membership, the general public still perceived European funds as external financing, although they were officially considered as public sources, like in other EU member countries (such as Hungary and Poland).

16. Among these ten countries (Cyprus, the Czech Republic, Estonia, Hungary, Latvia, Lithuania, Malta, Poland, Slovakia and Slovenia), two-namely Hungary and Poland-were part of our analysis.

17. Most of the social cooperatives were created thanks to the availability of EU funding, and the project's initiators were unable to sustain the social cooperatives when such funding came to an end. After 2010, social cooperatives became increasingly linked to the public-work programme funded by the government and linked to local municipalities.

18. In Albania, the IPA CSF 2016-2017 programme focused to a large extent on the development of civil society's capacities and on support to socialeconomy initiatives for inclusive development.

19. The IPA was also important, in the countries that joined the EU (Croatia, Hungary and Poland), before their accession.

20. Partners Albania is an NGO established in Albania in 2001. The organisation is a member of Partners Network, a partnership of 22 independent, local organisations in Europe, the Americas, Africa and the Middle East, working for peaceful and democratic change. Partners Albania is working to encourage the development of social entrepreneurship in Albania through seed funding, know-how and networking support for start-ups; it also works in evidence-based advocacy for an enabling institutional and financial environment for social enterprises (http://partnersalbania.org/).

21. British Council; see www.britishcouncil.vn/en/programmes/society/skillssocial-entrepreneurs (accessed on May 29, 2019).

22. Swiss cooperation with Eastern Europe; see www.eda.admin.ch/deza/en/ home/activities-projects/activities/cooperation-eastern-europe.html 
23. Switzerland is only member of the EFTA.

24. For a detailed overview of how civilian-based initiatives have become increasingly marginalised in Hungary in recent years, see Mihály (2019) and European Commission (2019).

25. A recent regional study (Varga 2017) also estimates that donors supporting social enterprises in CEE are mostly foreign. On the other hand, data from the ICSEM survey, which cover a sample of 105 social enterprises across CEE countries (Brolis 2019), suggest that SE income mostly comes from sales to private or public customers and public grants/subsidies.

26. In addition, social entrepreneurship is still relatively unknown to the general public in all the countries under consideration. The general public also has some reservations towards social enterprise due to the legacy of the "collective image" related to socialism (as for example in Croatia; see Vidović and Baturina 2016), which can hamper social-entrepreneurship development.

27. Large EU tenders can also encourage rent-seeking behaviours (European Commission 2019; Baturina 2016; Bežovan et al. 2016). This can account for the fact that social enterprises are more interested in carrying out activities in the fields that are financially supported.

\section{References}

Ashoka (2015) Társadalmi vállalkozók. Available HTTP: http://ashoka-cee. org/hungary/t\%C3\%A1rsadalmi-v\%C3\%A1llalkoz\%C3\%B3k (accessed on August 19, 2016).

Austin, J., Stevenson, H. \& Wei-Skillern, J. (2006) "Social and commercial entrepreneurship: Same, different, or both?” Entrepreneurship Theory and Practice, Vol. 30, No. 1, pp. 1-20.

Baturina, D. (2016) Utjecaj trećeg sektora na socio-ekonomski razvoj Republike Hrvatske, PhD dissertation, Zagreb: Faculty of Law.

Baturina, D. (2018) “A critical review of the first strategy for the development of social entrepreneurship in the Republic of Croatia 2015-2020 and Potential for the development of the sector", Hrvatska javna uprava: časopis za teoriju $i$ praksu javne uprave, Vol. 18, No. 2, pp. 11-38.

Bežovan, G., Matančević, J. \& Baturina, D. (2016) “Identifying external and internal barriers to third sector development in Croatia", TSI National Report Series, No. 5, Seventh Framework Programme (grant agreement 613034), European Union, Brussels: Third Sector Impact.

Borzaga, C., Galera, G. \& Nogales, R. (2008) Social Enterprise: A New Model for Poverty Reduction and Employment Generation. An Examination of the Concept and Practice in Europe and the Commonwealth of Independent States, Bratislava and Liege: UNDP and EMES International Research Network.

Brolis, O. (2019) ICSEM Data Set-Raw Data from Selected CEE Countries from ICSEM Questionnaire, Part 3.5., "Financial Structure as Reflected by Financial Statements”, Liege: The International Comparative Social Enterprise Models (ICSEM) Project (unpublished data).

Ciepielewska-Kowalik, A., Pieliński, B., Starnawska, M. \& Szymańska, A. (2015) "Social enterprise in Poland: Institutional and historical context", ICSEM Working Papers, No. 11, Liege: The International Comparative Social Enterprise Models (ICSEM) Project. 
Defourny, J. \& Nyssens, M. (2014) “The EMES approach of social enterprise in a comparative perspective”, in Defourny, J., Hulgård, L. \& Pestoff, V. (eds) Social Enterprise and the Third Sector. Changing European Landscapes in a Comparative Perspective, London: Routledge, pp. 42-65.

Di Domenico, M. L., Haugh, H. \& Tracey, P. (2010) "Social bricolage: Theorizing social value creation in social enterprises", Entrepreneurship Theory and Practice, Vol. 34, No. 4, pp. 681-703.

European Commission (2018) Social Enterprises and Their Ecosystems in Europe. Country Fiche: Serbia (Author: Cvejić, S.), Luxembourg: Publications Office of the European Union.

European Commission (2019) Social Enterprises and Their Ecosystems in Europe. Updated Country Report: Hungary (Authors: Kiss, J. \& Mihály, M.), Luxembourg: Publications Office of the European Union.

European Commission (2020) Social Enterprises and Their Ecosystems in Europe. Comparative Synthesis Report (Authors: Borzaga, C., Galera, G., Franchini, B., Chiomento, S., Nogales, R. \& Carini, C.), Luxembourg: Publications Office of the European Union. Available HTTP: https://europa.eu/!Qq64ny.

European Movement (2015) Strategic Study on Social Economy Development in the Context of the South East Europe 2020 Strategy, Belgrade: European Movement.

Evans, M. \& Syrett, S. (2007) “Generating social capital? The social economy and local economic development", European Urban and Regional Studies, Vol. 14 , pp. 55-74.

Eversole, R. (2014) "Social enterprises in rural community development", Community Development Journal, Vol. 49, No. 2, pp. 245-61.

Ferreira, S., Mihály, M., Nogales, R. \& Pongo, T. (2019) The Multi-Dimensional Reality of Social Enterprisein Central and Eastern Europe-Stakeholder Brief No. 1, EMPOWER-SE COST Action 16206. Available HTTP: www.empowerse.eu/wp-content/uploads/2019/03/SB1-WG1-Stakeholder-brief-Lisbon.pdf (accessed on October 2, 2019).

Fischer-Tahir, A. \& Naumann, M. (2013) "Introduction. Peripheralization as the social production of spatial dependencies and injustice", in Fischer-Tahir, A. \& Naumann, M. (eds) Peripheralization. The Making of Spatial Dependencies and Social Injustice, Wiesbaden: Springer VS, pp. 9-26.

Fougère, M., Segercrantz, B. \& Seeck, H. (2017) “A critical reading of the European union's social innovation policy discourse: (Re)legitimizing neoliberalism", Organization, Vol. 24, No. 6, pp. 819-43. Available HTTP: https://doi. org/10.1177/1350508416685171 (accessed on January 10, 2020).

Galera, G. (2016) "Social Enterprise in CEE and SEE: Trends and Challenges”, paper presented at Solidarity in Transition? Researching Social Enterprise in Post-Communist Societies: An International Scientific Colloquium, April 21-22, Tirana.

G. Fekete, É., Hubai, L., Kiss, J. \& Mihály, M. (2017) “Social enterprise in Hungary”, ICSEM Working Papers, No. 47, Liege: The International Comparative Social Enterprise Models (ICSEM) Project.

G. Fekete, É., Vicze, M. \& Hámori, G. (2014) A Map of Social Enterprises and Their Eco-systems in Europe-Country Report: Hungary, Brussels: European Commission. 
Havas, A. \& Molnár, G. (2017) “The evolution of social co-Operatives in Hungary-Organic development distorted by state interventions. The role of the state in economic development", paper presented at the 29th Annual EAEPE Conference, October 19-21, Budapest.

ICF (2014) A Map of Social Enterprises and Their Eco-systems in Europe, London: ICF Consulting Services Limited.

Ilijevski, K. \& Iloska, A. (2018) Country Fiche. Former Yugoslav Republic of Macedonia. Social Enterprises and Their Ecosystem in Europe, Luxemburg: Publication Office of the European Union.

Ilijevski, K., Iloska, A., Kusinikova, N. \& Mirchevski, V. (2016) Challenges and Opportunities for Employment of Marginalized Groups by Social Enterprises. Available HTTP: http://socialenterprisesbalkans.org/macedonia-en/wp-con tent/uploads/sites/3/2017/05/Challenges-and-opportunities-for-employmentof-marginalized-groups-by-social-enterprises-in-Macedonia11.pdf.

Ivanković-Knezević, K., Miličević, F., Sesar, I. \& Leonhardt Brlek, P. (2013) Peer Review on Social Entrepreneurship, Croatia 2013 - Host Country Report, Zagreb: Ministry of Labour and Pension.

Kadunc, M., Singer, S. \& Petricevic, T. (2014) A Map of Social Enterprises and Their Eco-systems in Europe-Country Report: Croatia, Brussels: European Union.

Kelemen-Varga, R., Kiss, J., Oravecz, Á., Bukovics, I., Száraz, A. \& Várnagy, E. (2017) 4 Year 448 Projects-Evaluation of the EEA Grants NGO Programme in Hungary, 2012-2017, Budapest: Hungarian Environmental Partnership Foundation.

Kral, D. (2013) "Common conclusions and recommendations", in Centre for Economic Development (ed) The Role of Civil Society in Development Assistance and Aid Effectiveness, Sofia: Centre for Economic Development.

Leś, E. \& Kolin, M. (2009) “East-central Europe”, in Kerlin, J. (ed) Social Enterprise. A Global Comparison, Medford: Tufts University Press.

Mihály, M. (2019) “Opposing peripheralization?” ACME: An International Journal for Critical Geographies, Vol. 18, No. 2, pp. 551-75. Available HTTP: https://acme-journal.org/index.php/acme/article/view/1559.

Ministerstvo Pracy/Polityki Spolecznej (2014) National Programme for Social Economy Development, Item 811, Vol. 1, Warsaw: Ministerstvo Pracy/Polityki Spolecznej.

Mosse, D. (2005) "Introduction: The ethnography of policy and practice", in Mosse, D. (ed) Cultivating Development: An Ethnography of Aid Policy and Practice, London and Ann Arbor: Pluto Press.

OECD (2006) Reviewing OECD Experience in the Social Enterprise Sector, Paris: OECD.

Pape, U., Chaves-Ávila, R., Pahl, J. B., Petrella, F., Pieliński, B. \& Savall-Morera, T. (2016) "Working under pressure: Economic recession and third sector development in Europe", International Journal of Sociology and Social Policy, Vol. 36, Nos. 7/8, pp. 547-66.

Partners Albania (2013) Development of Social Enterprises. Potential for Job Creation for Disadvantaged Groups, Tirana: Partners Albania.

Partners Albania (2016) Challenges and Opportunities for Employment of Marginalized Groups by Social Enterprises, Tirana: Partners Albania. 


\section{Baturina, Mihály, Haska et al.}

Pike, A., Rodríguez-Pose, A. \& Tomaney, J. (2006) Local and Regional Development, New York and Abingdon: Routledge.

Radaelli, C. (2004) “Europeanisation: Solution or problem?” European Integration Online Papers, Vol. 8, No. 16. Available HTTP: http://eiop.or.at/eiop/ texte/2004-016a.htm.

Republički zavod za statistiku (2014) Ekonomski uticaj socijalnih preduzeća $u$ Srbiji, Beograd: SeConS grupa za razvojnu inicijativu, Grupa 484.

Šimleša, D., Bušljeta Tonković, A. \& Puđak, J. (2016) “Društveno poduzetništvo u Hrvatskoj: od prepoznavanja do primjene", Revija za sociologiju, Vol. 46, No. 3, pp. 271-95. Available HTTP: https://doi.org/10.5613/rzs.46.3.2.

Spurga, S. (2007) "Europeanization of civil society in the baltic states: Promotion or constraint of democratization?" Vieðoji politika ir administravimas, Vol. 22, pp. 57-68.

Srbijanko, K. J., Korunovska, N. \& Bashevska, M. (2016) Social Enterprises and Work Integration of Vulnerable Groups in Macedonia, Albania and Kosovo, Skopje: Reactor-Research in Action. Available HTTP: http://reactor.org.mk/ CMS/Files/Publications/Documents/SocialEnterprisesMKALKV.pdf.

Szabó, M. \& Márkus, E. (2015) "Civil society in Hungary", in Schreier, C. (ed) 25 Years After Mapping Civil Society in the Visegrád Countries, Berlin: Maecenata Institute for Philanthropy and Civil Society.

Tóth, L., Varga, É. \& Varga, P. (2011) A társadalmi vállalkozások belyzete Magyarországon, Budapest: NESsT.

Vandor, P., Traxler, N., Millner, R. \& Meyer, M. (2017) Civil Society in Central and Eastern Europe: Challenges and Opportunities, Vienna: ERSTE Foundation.

Varga, E. (2017) Social Enterprise Ecosystems in Croatia and the Western Balkans-A Mapping Study of Albania, Bosnia \& Herzegovina, Croatia, Kosovo, FYR Macedonia, Montenegro and Serbia, Zagreb: NESsT.

Vidović, D. (2012) Socijalno poduzetništvo u Hrvatskoj, PhD dissertation, Zagreb: Filozofski fakultet, Sveučilište u Zagrebu.

Vidović, D. (2019) Social Enterprises and Their Eco-systems in Europe. Updated Country Report: Croatia, European Commission, Luxembourg: Publications office of the European Union.

Vidović, D. \& Baturina, D. (2016) "Social enterprise in Croatia: Charting new territories”, ICSEM Working Papers, No. 32, Liege: The International Comparative Social Enterprise Models (ICSEM) Project. 